\title{
Endophytic Fungi Isolated from Rhizophora mucronata and Their Antibacterial Activity
}

\author{
Kapang Endofit yang Diisolasi dari Rhizophora mucronata \\ dan Aktivitas Antibakterinya \\ Kustiariyah Tarman*, Dwi Safitri, and Iriani Setyaningsih ${ }^{1}$ \\ ${ }^{1}$ Department of Aquatic Product Technology, Faculty of Fisheries and Marine Sciences Bogor Agricultural University, \\ Kampus IPB Darmaga, Jl. Agatis, Bogor 16680 West Java, Indonesia \\ ${ }^{*}$ Corresponding author: kustya@gmail.com \\ Article history: \\ Received: 4 August 2012; Revised:10 May 2013; Accepted: 10 May 2013
}

\begin{abstract}
Mangrove plants are known as source of traditional medicines. Endophytic fungi have an important economic potential for antibacterial, enzyme and secondary metabolites that are useful especially in pharmaceutical industry. The purpose of this research was to determine the antibacterial activity of the endophytic fungal extracts from mangrove plant Rhizophora mucronata against diarrhea causing bacteria. This research included isolation, characterization, cultivation, extraction, and antibacterial activity test. The study yielded 5 types of endophytic fungi with different morphology. Endophytic fungus DS1 was the selected isolate based on antagonism test. The growth pattern showed the stationary phase of isolate DS1 was on the $15^{\text {th }}$ day. Culture broth extract showed considerable inhibition on Pseudomonas aeruginosa with diameter of inhibition zone was $18.5 \mathrm{~mm} \pm 3.32$. Extract of mycelium inhibited the growth of Staphylococcus aureus (2 $\mathrm{mm}$ ). The culture broth extract showed more potent antibacterial activity in comparison with the mycelium extract.
\end{abstract}

Keywords: antibacterial, diarrhea, endophytic fungi, mangrove

\begin{abstract}
ABSTRAK
Tumbuhan mangrove merupakan sumber bahan obat tradisional. Kapang endofit memiliki potensi ekonomi yang penting sebagai sumber antibakteri, enzim dan metabolit sekunder lain yang bermanfaat khususnya pada industri farmasi. Tujuan penelitian ini untuk menentukan aktivitas antibakteri ekstrak kapang endofit dari mangrove Rhizophora mucronata terhadap bakteri penyebab diare. Tahapan penelitian yang dilakukan meliputi isolasi kapang endofit, karakterisasi, kultivasi, ekstraksi, dan pengujian aktivitas antibakteri. Studi ini menghasilkan 5 isolat kapang dengan morfologi berbeda. Kapang DS1 merupakan isolat terpilih dari hasil uji antagonisme. Kurva pertumbuhan kapang menunjukkan bahwa kapang DS1 mencapai fase stasioner pada hari ke-15. Ekstrak media kultur menunjukkan daya hambat paling besar terhadap Pseudomonas aeruginosa yaitu $18.5 \mathrm{~mm} \pm 3.32$. Zona hambat ekstrak miselium paling besar terhadap Staphylococcus aureus yaitu sebesar $2 \mathrm{~mm}$. Ekstrak media kultur lebih efektif sebagai antibakteri dibandingkan dengan ekstrak miselium.
\end{abstract}

Kata Kunci: antibakteri, diare, kapang endofit, mangrove

Permalink/DOI: http://dx.doi.org/10.15578/squalen.v8i2.88

\section{Introduction}

Mangrove is one of the rare and distinctive ecosystems in the world, due to the extent of only $2 \%$ of the earth's surface. This ecosystem has an important role in the ecological, socio-economic, and socio-cultural aspects (Setyawan \& Winarno, 2006). Mangrove is a source of traditional medicine that contains bioactive compounds with antimicrobial, antifungal, antiviral, antitumor, insecticide and antileukemia activities (Soetarno, 2000). One of the plants possessing these characteristics is Rhizophora mucronata. Traditionally, coastal community uses this plant for treating hematuria (bleeding in the urine). In Japan and China this mangrove is used as an antidiarrheal (Rahman et al., 2011).

Plants with a history of traditional uses by local people in Japan and China were suggested to have specific secondary metabolites, and expected to be a host for endophytic fungi. Several studies on endophytic microbes showed that endophytic fungi 
have significant economic potential especially in the pharmaceutical industry (Kumala \& Fitri 2008). The results of Melliawati and Wulandari study (2008) showed that the endophytic fungi of Halimun Mountain National Park could inhibit the growth of microbial pathogens Salmonella typhi and Candida albicans, and additionally according to Melliawati \& Harni (2009), those endophytic fungi could inhibit the growth of Escherichia coli and Staphylococcus aureus.

Diarrheal disease remains a public health problem in developing countries such as Indonesia. In 2010, an extraordinary events of diarrhea (Kejadian Luar Biasa, KLB) has ocured in which the number of patients was 4204 , and 73 people of them died (KKRI, 2011). Diarrhea usually occurs due to poor environmental sanitation. In 1995 to 2001, diarrhea patients from several provinces in Indonesia such as Jakarta, Padang, Medan, Denpasar, Pontianak, Makassar and Batam has suffered from Shigella sp., Salmonella sp., Vibrio parahaemolyticus, Salmonella typhi, Campylobacter jejuni, and Salmonella paratyphi, but the most common cause was Vibrio cholerae (Zein et al., 2004).

Bacteria such as Shigella flexneri, Staphylococcus aureus, Escherichia coliand Salmonella typhi are also reported causing diarrhea (Umer et al., 2013). Pseudomonas aeruginosa causes infectious diarrhea which usually represents a nosocomial infection in an immunocompromised host (Porco \& Visconte, 1995; Kim et al., 2001). Diarrhea is the leading cause of death in children under 5 years (Fagundes-Neto \& Scaletsky, 2000). In developing countries enteropathogenic Escherichia coli (EPEC) is a major cause of infantile diarrhea. EPEC poses a significant health threat to children worldwide (Vallance \& Finlay, 2000).

Ability of endophytic microbes to produce bioactive compounds is a challenging opportunity in the provision of raw materials for drugs (Strobel et al., 2004). The use of endophytic microbes as a source of raw materials for drugs is expected to be more efficient economically than using medicinal plants (Sinaga et al., 2009). This study aimed to obtain isolates of endophytic fungi from mangrove plant Rhizophora mucronata, to characterize the endophytic fungal isolates, and to determine the antibacterial activity of the fungal extracts against diarrhea-causing bacteria.

\section{Material and Methods}

Fungal isolates used in this study were isolated from leaves of Rhizophora mucronata collected at Taman Wisata Alam Angke Kapuk, North Jakarta.
Chemicals and culture media used were solvents and microbiological culture media. Reagents used were for phytochemical test.

The research stages included preparation of Rhizophora mucronata mangrove leaves, isolation of endophytic fungi using surface sterilization method and then leaves inoculated into Potato Dextrose Agar (PDA) medium and incubated at room temperature $\left(27-29^{\circ} \mathrm{C}\right.$ ) for $2-14$ days (Tarman, 2011). Subsequently, the fungi were selected through antagonism test to get a potential isolate for further antibacterial activity assay. Selected fungal isolates then were characterized macroscopically and microscopically.

Growth of the fungus was determined based on the dry weight of the fungal biomass (Tarman, 2011) for 18 days of cultivation in which it was sampled for each 3 days. During cultivation the $\mathrm{pH}$ of the medium was measured. Cultivation for bioactive production was conducted for 15 days. Harvesting was performed by separating culture medium and the mycelia. Then, the mycelia were extracted using methanol and the culture medium extracted with ethyl acetate (Tarman, 2011). Both methanol and ethyl acetate extracts were tested for their antibacterial activity against diarrhea causing bacteria (enteropathogenic Escherichia coli (EPEC), Escherichia coli, Staphylococcus aureus, Pseudomonas aeruginosa and Salmonella typhi) with extract concentration used were $0.5 \mathrm{mg}, 1 \mathrm{mg}$ and 2 $\mathrm{mg}$, chloramphenicol as a positive control and related solvent as a negative control. Diameter of inhibition zone was measured using a ruler. Antibacterial activity test was performed after Moorthy et al. (2007) using agar well diffusion method. The potential of the antibacterial activity was classified after Davis \& Stout (1971). They classified antibacterial activity into four categories based on diameter of the inhibition zone, namely (1) weak if lower than $5 \mathrm{~mm}$, (2) medium ranges $5-10 \mathrm{~mm}$, (3) strong if $10-20 \mathrm{~mm}$, and (4) very strong if $20 \mathrm{~mm}$ or more. Phytochemical test of mycelia extracts was conducted for alkaloids and phenolic compounds analyses (Harborne, 1987).

\section{Result and Discussion}

\subsection{Fungal Endophytes from Rhizophora mucronata}

Plants and microorganisms interact closely with one another, such as microgranisms living inside the plant's tissue (endophytic microbes). Endophytic microbes i.e., microbes that grow in the tissues of plant can be found in almost all plants on earth (Strobel et al. 2004). In this study, 5 endophytic fungi were successfully isolated from leaves of Rhizophora mucronata. The isolates were morphologically different as can be seen in Table 1. 
Table 1. Fungal isolates from Rhizophora mucronata

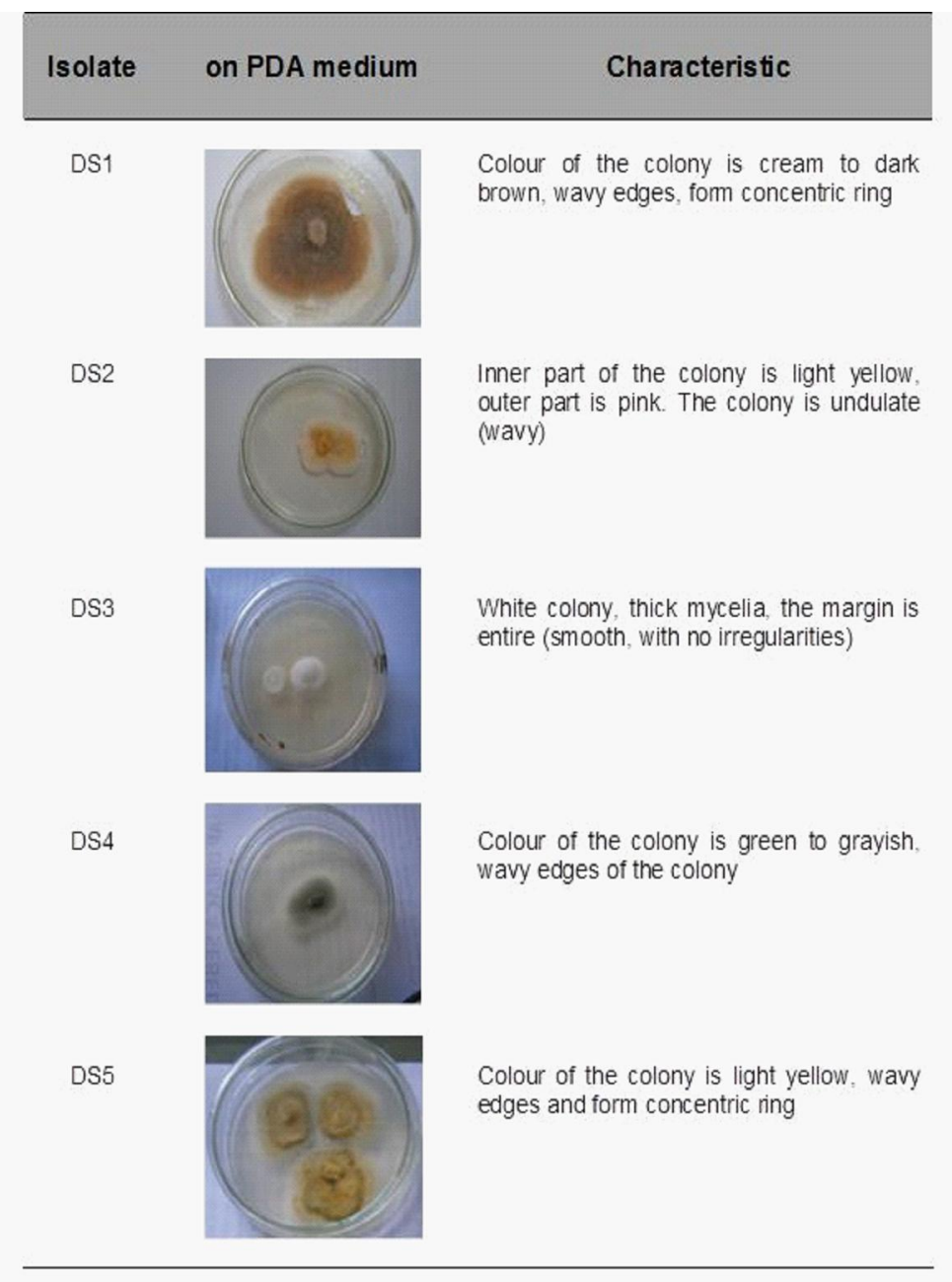

Isolates DS4 dan DS5 were suspected as Aspergillus sp. based on the macroscopic characteristics. Extracts of Aspergillus sp. could inhibit the growth of Escherichia coli, Pseudomonas aeruginosa, and Bacillus subtilis, as well as showed antifungal activity (Bugni et al., 2000). Isolates DS1, DS2 and DS3 have not been identified.

\subsection{Selected Fungal Endophytes}

Fungal isolate used for further study was selected using antagonism test. This test was performed to observe the most dominant endophytic fungus (Figure 1). Antagonism test of isolates DS1, DS2 and DS3 indicated that isolate DS1 grew more dominantly in comparison with isolates DS2 and DS3.

Mechanism of antagonist on microorganisms can occur in three ways: direct parasitism, antibiosis by producing secondary metabolites (toxins) and competition in terms of space and nutrient requirements (Pradana et al., 2013). Isolate DS1 showed antagonistic mechanisms against isolates DS2 and DS3. Isolate DS1 was more competitive in terms of space used as can be seen from the growth pattern of the fungus over the other isolates. The different level of inhibition activity of endophytic fungi allegedly closely associated with the ability of endophytic fungi to compete with pathogens. In addition, endophytic fungi have antifungal properties that can inhibit the growth of other fungi (Sudantha \& Abadi, 2007).

No inhibition zone was observed in this antagonism test. The results demonstrated that the two fungi in the same plate showed neutralism interaction. This may be due to one fungus produces antifungicides and the other detoxifies the compounds (Tsujiyama \& Minami, 2005).

\subsection{Characteristics of Fungal Endophytes}

Isolate DS1 was observed based on macroscopic and microscopic characteristics (Figure 2). Colonies 


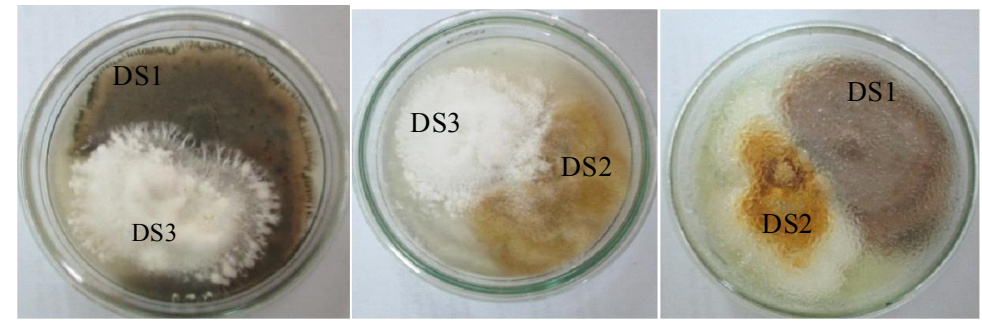

(a)

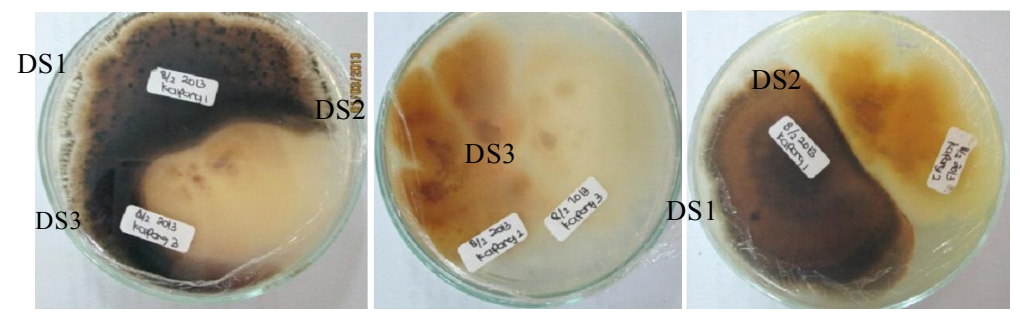

(b)

Figure 1. Antagonism test of the fungal isolates for 11 days (a) top view, (b) bottom side view.

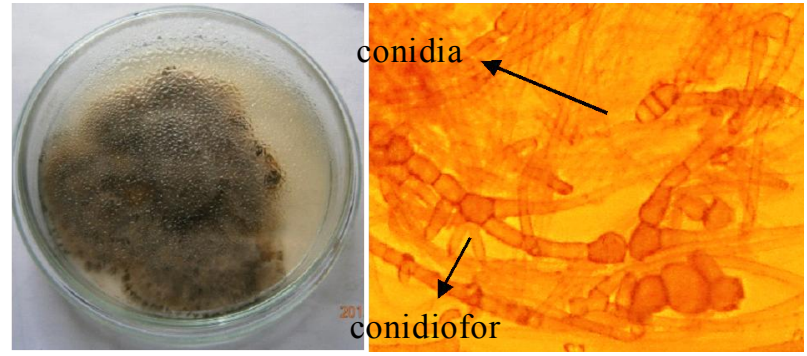

(a)

(b)

Figure 2. DS1 Isolate (a) 11 days old, (b) hyphae (400x).

of the fungus are brown to black with wavy edges and form concentric configuration. Microscopically, the fungus has septate hyphae, 2-septate conidia, and in chain form. The isolate was further observed morphologically and according to Gandjar et al. (2000), it was proposed to belong to the genus Alternaria. Previous study on Alternaria showed that the extracts exhibited high activity in inhibiting the growth of pathogenic microorganisms, Staphylococcus aureus and Candida albicans with corresponding inhibition zone was $27 \mathrm{~mm}$ and $16 \mathrm{~mm}$ (extract concentration of $1 \mathrm{mg} / \mathrm{ml}$ ) (Fernandes et al., 2009).

\subsection{Fungal Growth}

The growth of fungus DS1 was determined by the weight of dried fungal biomass. The $\mathrm{pH}$ of the medium was measured during fungal cultivation. The growth curve of the fungus is presented in Figure 3 . The $\mathrm{pH}$ changes of the fermentation medium are caused by the metabolic activity of the fungi. In this study the $\mathrm{pH}$ value of the fungus during cultivation was 4 (Figure
3). Commonly, the optimum pH of the fungal growth ranges from 4 to 7 (Srikandace et al., 2007).

The fungal growth curve showed that the lag phase of the fungus was until day 6 . The exponential growth phase was on day 6 to 9 , as can be seen from the considerable increase of the biomass. After day 9 to day 15 , the growth curve showed that the fungus was in stationary phase. Generally, secondary metabolites are produced during this phase (Srikandace et al., 2007). In this phase the fungal cells are more resistant to extreme conditions. Synthesis of secondary metabolites begins with the nutrient depletion of the growth medium. This can lead to the production of substances which are the result of catabolism of secondary metabolites. Since day 18 the fungus was in death phase.

\subsection{Antibacterial Activity against Diarrhea-caus- ing Bacteria}

The preliminary study showed that the bioactive compounds were highly produced on day 15 . 


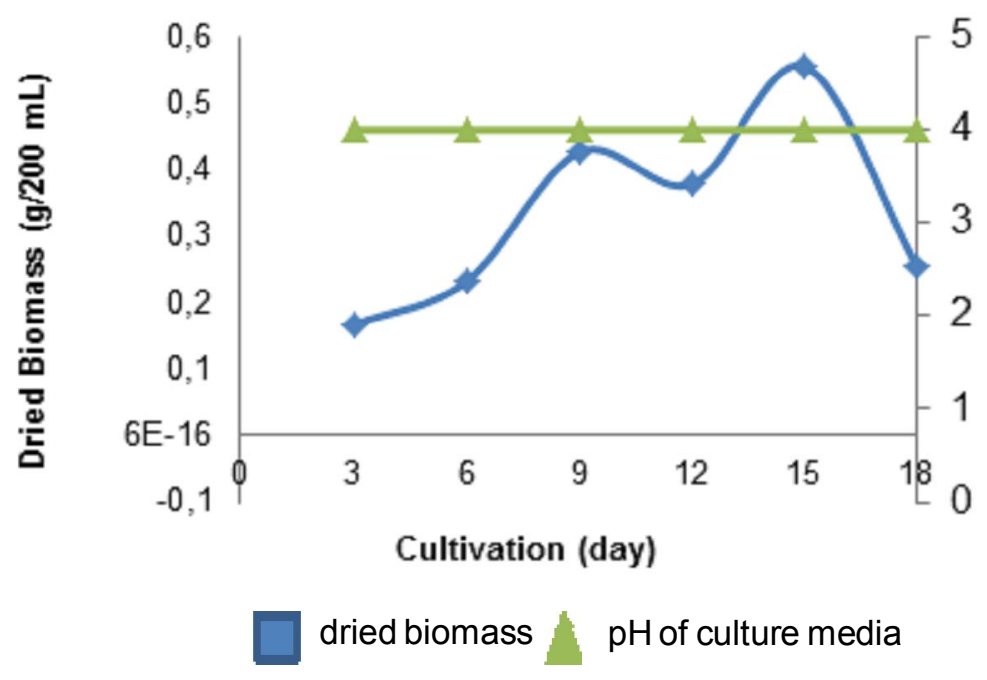

Figure 3. Growth of DS1 isolate for 18 days.

Additionally, the extracts exhibited highest activity; therefore the fungus was cultured for 15 days. Antidiarrheal potential of the extracts was determined by antibacterial activity test against diarrhea-causing bacteria.

\subsection{Antibacterial Activity of Culture Broth Extracts}

Ethyl acetate extract of culture broth obtained was $29.38 \%(w / v)$. Subsequently, the extracts were tested against the test bacteria. Result of the antibacterial activity tests of culture broth extracts is presented in Figure 4.
The results showed that the extract of the culture broth could inhibit the growth of all test bacteria from a concentration of $0.5 \mathrm{mg}$. The ethyl acetate extracts were considerably inhibited the growth of Pseudomonas aeruginosa and Escherichia coli, while Salmonella typhii was the most resistant bacterium to the extracts tested. From this result, it can be roughly concluded that the ethyl acetate culture-broth extracts were more effective to inhibit the growth of Gram-negative bacteria. This result was similar to the study of Maria et al. (2005) on endophytic fungi of mangrove. Extracts of the fungal culture broth exhibited highest activity against Pseudomonas

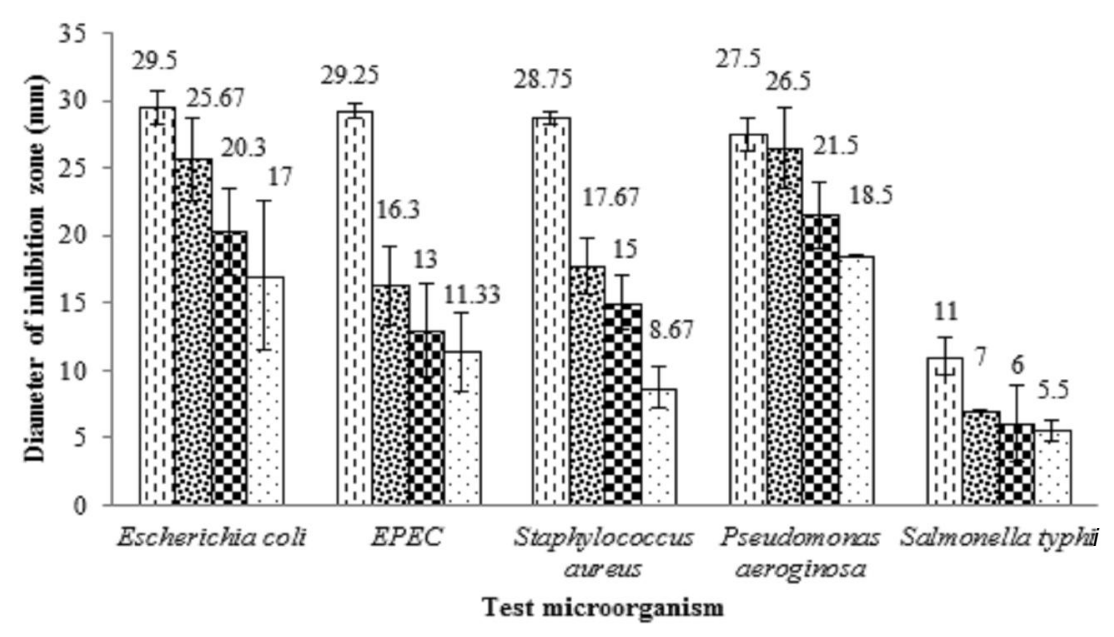

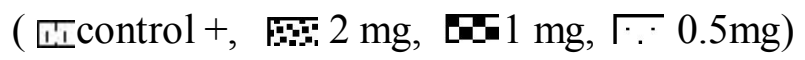

Figure 4. Antibacterial activity of culture broth extracts. 


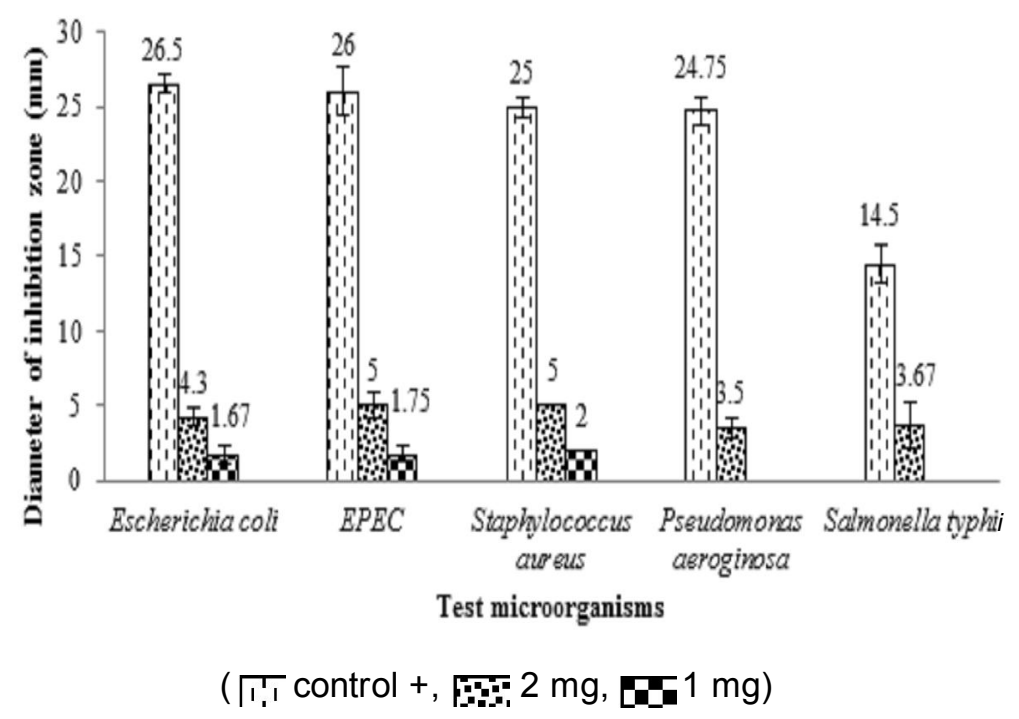

Figure 5. Antibacterial activity of mycelial extracts.

aeruginosa, on the other hand Salmonella typhii was the most resistant.

\subsection{Antibacterial Activity of Mycelia Extracts}

Yield of the mycelial extracts was $26.34 \%$ (w/w). Intracellular metabolites which are contained in the mycelia, namely polysaccharides, proteins, lipids and nucleic acids are the main constituent of the primary metabolites. Mycelial extracts were also tested against the test bacteria. Figure 5 shows the antibacterial activity of mycelial extracts.

Antibacterial test results indicated that the mycelia extract showed the highest inhibition activity against Staphylococcus aureus, while the lowest activity was against Pseudomonas aeruginosa. Antibacterial activity of the mycelial extracts was noticeably lower in comparison with the activity of culture broth extracts.

The results showed that the diameter of inhibition zone indicating antibacterial activity of the extracts was diverse. This is due to the sensitivity of each bacterium to extracts tested was also varied. Study of Dali et al. (2011) reported that each bacterium possesses different biological capabilities in response to antibacterial agents. One of the most influential factors to the antibacterial activity is the structural differences between the bacterial cell wall of Gramnegative and Gram-positive bacteria.

Some factors affect the antibacterial activity of the compounds, such as the concentration or intensity of the antimicrobial agents, the number of microorganisms tested, species of microorganisms, temperature, the present of organic matter, acidity and alkalinity (pH) (Pelczar \& Chan, 2008).
The results showed that the extracts of the culture medium exhibited much higher antibacterial activity compared to the mycelial extracts. This is similar to the results of other studies on biological activities of mycelial and culture broth extracts of the fungi (Jung et al., 2002; Nursid et al., 2010; Tarman et al., 2011).

Kusuma et al. (2011) reported that the methanol extract of the mangrove $R$. mucronata leaves could inhibit the growth of $B$. subtilis, $S$. aureus, and $P$. aeruginosa with an inhibition zone diameter correspondingly was $18 \mathrm{~mm}, 16 \mathrm{~mm}$ and $14 \mathrm{~mm}$. By comparing Kusuma's study with this experiment, it could be roughly sum up that the extracts of the fungal endophytes of $R$. mucronata exhibited higher activity than those of the leaves. Strobel et al. (2004) also reported that the extracts of endophytic fungi from $R$. mucronata showed higher activity than those of the host plant.

\subsection{Bioactive Components}

Bioactive components of the extracts can be determined using phytochemical test. Phytochemical test is a qualitative test used to determine the content of secondary metabolites present in the sample (Copriyadi et al., 2005). In this study, phytochemical test was performed to identify the present of alkaloids and phenol hydroquinone in mycelia extracts. Lumyong et al., (2004) stated that the fungal endophyte produces alkaloids and mycotoxins that may be used to improve plant resistance to disease. Phenolic compound is one of the compounds that can inhibit the metabolism of cells. Phytochemical test results showed that the alkaloids and phenolic hydroquinone compounds were not detected in the 
mycelial extract of the endophytic fungus. These results clarify the reason that antibacterial activity of mycelial extracts was considerably lower compared to the extracts of culture broth.

\section{Conclusion}

Five fungal endophytes with different morphology were isolated from Rhizophora mucronata leaves. The selected fungus, isolate DS1 was suspected as Alternaria based on its macroscopic and microscopic characteristics. After 15 days of cultivation, the fungus was in the stationary phase and at this time produced metabolites with highest antibacterial activity. Ethyl acetate extracts of the fungal culture broth showed more potent antibacterial activity compared to the mycelial extracts.

\section{References}

Bugni, T.S., Abbanat, D., Bernan, V. S., Maiese, W. M., Greenstein, M., Wagoner, R. M. V., \& Ireland, C. M. (2000). Yanuthones: Novel metabolites from a marine isolate of Aspergillus niger. Journal of Organic Chemistry. 65, 7195-7200.

Copriyadi, J., Yasmi, E., \& Hidayati. (2005). Isolation and characterization of coumarines from peels of orange (Citrus hystrix DC). Jurnal Biogenesis. 2, 13-25.

Dali, S., Natsir, H., Usman, H., \& Ahmad, A. (2011). Antibacterial bioactivity of protein fractions of red seaweed Gelidium amansii from Cikoang water, Takalar Regency, South Sulawesi. Majalah Farmasi dan Farmakologi. 15(1): 47-52.

Davis, W.W. and Stout, T.R. 1971. Disc plate methods of microbiological antibiotic assay. Microbiology. 22(4): 659-665.

Fagundes-Neto, U. and Scaletsky, ICA. 2000. The gut at war: the consequences of enteropathogenic Escherichia coli infection as a factor of diarrhea and malnutrition. Sao Paulo Med. J. 118(1).

Fernandes, M. R. V., Costa, e Silva, T. A., Pfenning, L. H., da Costa-Neto, C. M., Heinrich, T. A., de Alencar S. M., de Lima, M. A., \& Ikegaki, M. 2009. Biological activities of the fermentation extract of the endophytic fungus Alternaria alternata isolated from Coffea arabica L. Brazilian Journal of Pharmaceutical Sciences. 45(4), 677-686.

Gandjar, I., Samson, R.A., Vermeulen, Oetari, A., and Santoso, I. (2000). Introduction to Common Tropical Fungi. Jakarta: Yayasan Obor Indonesia.

Harborne, J.B. (1987). Phytochemical Methods. $2^{\text {nd }}$ ed. Padmawinata K, Soediro I (translator). Bandung: ITB.

Jung, D. S., Na Y. J., \& Ryu K.H. (2002). Phylogenic Analysis of Alternaria brassicicola Producing Bioactive Metabolites. The Journal of Microbiology. 40(4), 289-294

Kim, S. W., Peck. K. R., Jung, S. I., Kim, Y. S., Kim, S, Lee, N. Y., \& abd, Song, J. H. (2001). Pseudomonas aeruginosa as a potential cause of antibioticassociated diarrhea. J. Korean Med. Sci. 16(6), 7424.

[KKRI] Ministry of Health of Republic of Indonesia. (2011). Diarrhea in Indonesia. Buletin Jendela Data dan Informasi Kesehatan. Retrieved from http:// depkes.go.id. Accessed at 19 Oktober 2012.

Kumala, S. \& Fitri, N. A. (2008). Screening of endophytic fungi of Shorea balangeran Korth bark as xylanase source. Jurnal IImu Kefarmasian Indonesia. 6(1), 16.

Kusuma, S., Kumar, P. A., \& Boopalan, K. (2011). Potent antimicrobial activity of Rhizophora mucronata. Journal of Ecobiotechnology. 3(11), 40-41.

Lumyong, S., Lumyong, P., \& Hyde, K. D. (2004). Endophytes. In Jones, E. B. G., M. Tantichareon and K. D. Hyde (Ed.), Thai Fungal Diversity. BIOTEC Thailand and Biodiversity Research and Training Program (BRTI/TRF. Biotec). 197-212.

Maria, G. L., Sridhar, K. R., \& Raviraja, N. S. (2005). Antimicrobial and enzyme activity of mangrove endophytic fungi of southwest coast of India. Journal of Agricultural Technology. 1: 67-80.

Melliawati, R. \& Harni. (2009). Antibacterial compounds against Escherichia coli ATCC 35218 and Staphylococcus aureus ATCC 25923 from endophytic fungi from Halimun Mountain National Park. Jurnal Natur Indonesia. 12(1), 21-27.

Melliawati, R. \& Wulandari, P. S. (2008). Endophytic fungi from Halimun Mountain National Park as growth inhibitor of pathogenic microbes Salmonella typhi and Candida albicans. Berkas Penelitian Hayati.13, 101-107.

Moorthy, K., Srinivasan, K., Subramanian, Palaniswamy, M., \& Mohanasundari, C. 2007. Phytochemical screening and antibacterial evaluation of stem bark of Mallotus philippinensis var. Tomentosus. African Journal of Biotechnology. 6(13), 1521-1523.

Nursid, M., Pratitis, A., \& Chasanah, E. (2010). Cultivation of fungus MFW-01-08 isolated from ascidia Aplidium longithorax and its cytotoxic activity test against breast cancer cell line T47D. Jurnal Pascapanen dan Bioteknologi Kelautan dan Perikanan. 5(2), 103-110.

Porco, F. V. and Visconte, E. B. (1995). Pseudomonas aeruginosa as a cause of infectious diarrhea successfully treated with oral ciprofloxacin. Ann Pharmacother. 29(11), 1122-3.

Pradana, G. S., Ardyati, T., \& Lukman, Q. A. (2013). Exploration of antagonistic and pathogenic fungi on apple tree in apple trial field in Poncokusumo. Biotropika. 1(1), 14-18.

Pelczar, M. J. \& Chan, E. S. C. (2008). Elements of Microbiology. $2^{\text {nd }}$ ed. Hadioetomo et al. (translator). Jakarta: UI:-Press.

Rahman, M. A., Hasan, S. N., Sampad, K. S., \& Das, A.K. (2011). Antinociceptive, antidiarrhoeal and cytotoxic activities of Rhizophora mucronata lamk. Journal of Pharmacologyonline. 1: 921-929. 
Setyawan, A.D. \& Winarno, K. (2006). Direct utilization of mangrove ecosystem in Central Java and land use in surrounding: damage and restoration efforts. Jurnal Biodiversitas. 7(3), 282-291.

Sinaga, E., Noverita, \& Fitria, D. (2009). Antibacterial activity of endophytic fungi isolated from leaves of galangal (Alpinia galangal SW). Jurnal Farmasi Indonesia. 4(4), 161 -170.

Soetarno, S. (2000). Potential and benefits of mangrove plants as source of bioactive compounds. Acta Pharmaceutica Indonesia. 12(4), 84-103.

Srikandace, Y., Hapsari, Y. \& Simanjuntak, P. (2007). Selection of endophytic microbes of Curcuma zedoaria in producing antimicrobial compounds. Jurnal IImu Kefarmasian Indonesia. 5(2), 77-84.

Strobel, G., Daisy, Castillo, \& Harper, J. (2004). Natural product from endophytic microorganism. J. Nat. Prod. 67, 257- 268.

Sudantha, I. M. \& Abadi, A. L. 2007. Identification of endophytic fungi and their anatgonistic mechanism against Fusarium oxysporum f. sp. Vanillae in vanilla tree. Jurnal Agroteksos. 17(1), 23-38.
Tarman, K. (2011). Biological and Chemical Investigations of Indonesian Marine-Derived Fungi and their Secondary Metabolites. Göttingen: Cuvillier Verlag.

Tarman, K., Lindequist, U., Wende, K., Porzel, A., Arnold, N., \& Wessjohann, L. A. (2011). Isolation of a new natural product and cytotoxic and antimicrobial activities of extracts from fungi of Indonesian marine habitats. Marine Drugs. 9(3), 294-306.

Tsujiyama, S. \& Minami, M. (2005). Production of phenoloxidizing enzymes in the interaction between whiterot fungi. Mycoscience. 46, 268-271.

Umer, S., Tekewe, A., \& Kebede, N. (2013). Antidiarrhoeal and antimicrobial activity of Calpurnia aurea leaf extract. BMC Complementary and Alternative Medicine. 2013, 13/21.

Vallance, B. A., \& Finlay, BB. (2000). Exploitation of host cells by enteropathogenic Escherichia coli. Proc. Natl. Acad. Sci. USA. 97(16), 8799-806.

Zein, U., Sagala, K. H., \& Ginting, J. (2004). Acute diarrhea caused by bacteria. Repository Fakultas Kedokteran. Sumatera Utara: Universitas Sumatera Utara: 1-15 